\title{
Situation of Metrology Education in Developing Countries using Nigeria as a Case Study
}

\author{
S.M. Ibrahim, P. Bills, J.M. Allport \\ University of Huddersfield \\ United Kingdom
}

\begin{abstract}
Metrology is quite an unusual profession, but it is widely encountered and very significant in our everyday life. However, metrologists are few and most universities don't even mention the subject. How, then, do metrologists get an education? This paper aims to address metrology education in developing countries, to enhance developing countries' awareness of the significance of metrology education and the need for it to be introduced into universities academic curricula.

The impediment of metrology education is much more widespread in developing countries than the developed countries. To substantiate the level of metrology education in developing countries, Nigeria has been used as a case study. Research which examined knowledge related to metrology in general, flow and legal metrology was conducted across six Universities. Assessment of the students revealed they substantially lacked the abilities required in all area of metrology knowledge.

Considering the general significance of metrology, this paper therefore recommends that the curricula of engineering schools, technical universities and other special training institutes should contain at least some basic courses on metrology. Also recommended is the formation of consortia of institutions comprised of educational institutions, industry practitioners, and regulators. This paper also highlights the requirement for a suitable metrology education for practitioners within statutory bodies.
\end{abstract}

\section{Introduction}

Metrology (the science of measurement and it applications) is quite unusual as a profession but it is encountered very widely in practice, from measurement systems or instrument design to calibration works, scientific research, and everyday life. Some aspects of metrology concern the establishment of quantity systems, unit systems and units of measurement; the development of new measurement methods; realisation of measurement standards and the transfer of traceability from these standards to users in society. Others cover the application of measurement science to manufacturing and other processes and their use in society [1], while yet others are concerned with applying regulatory structure and enforcement to metrology. Some practitioners design measurement systems or instruments. Others perform calibrations. Still others do basic research into underlying scientific principles. The legislation of many new products and technologies depends on metrology [2].

Metrology is an integral component of the technical infrastructure value chain. Traceability to national measurement standards, which is one of the key element of metrology, is fundamental, for instance, to the optimisation of disease diagnosis and health care, forensic science, occupational health and safety, production, consumer confidence and protection, food safety and environmental monitoring,. Principles of measurement and observation remain fundamental regardless of application, they apply to every measurement and observation made in every lab anywhere on the planet. As noted in the study of Vosk [3], physicist Lord Kelvin said over a century ago, “...if science is measurement, then without metrology there can be no science".

Metrology is multi-disciplinary. In application, it enables measurements of quantities to be related to one another in a true and absolute sense. Measurement is the essential tool by which humans describe the world and reason about it. If measurements are flawed, analyses and interpretations based on these measurements are fundamentally and irreparably fallacious [4]. Considering the large variety of applications in the field, one can imagine how broad the subject matter is.

Metrology is everywhere, but specialist metrologists are few and most curricula in technical fields don't even mention metrology. How, then, do metrologists acquire an education? Considering the significant of metrology, it is necessary to create awareness of the need to introduce metrology curricula into those scientific and technical fields in universities, most especially in the developing world. With the increased emphasis on the equivalence of measurement and testing services for quality of life, environmental protection and trade, this is particularly important for the economic development of those countries. This paper considers with 
particular interest, metrology education in developing countries with the aim of enhancing those countries' awareness of the significance of metrology education and the need for it to be introduced into university level academic curricula. This paper will also provide background information on educational institutions offering metrology programs or classes in developing countries for the benefit of the prospective students.

\section{Importance of metrology - Why do we measure?}

Metrology in support of efficiency and innovation in industry is not, however, the only subject of this paper. This paper will speak about the impact which measurements make on all of us in our everyday lives. We benefit from a wide range of measurements which are routinely carried out in our interest, many of which go unnoticed. As illustrated in Figure 1, measurements are met in almost all human activities.

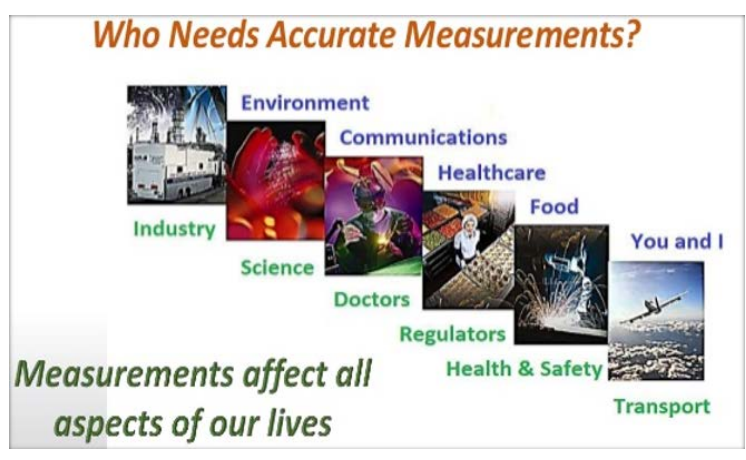

Figure 1. Metrology benefits [5]

The following briefly describe the significant of metrology, although it is a far-from-complete list of some of the larger and more important fields of use:

i. Metrology aid in industry: Metrological characteristics undoubtedly, concern industry. Industry has to set up analytical systems in such a way that they allow modifications in procedures and adaptation to analytical progress without harming internal comparability. This includes the maintenance of traceability for basic measurement methods (masses, time, etc.). For biological and chemical measurements, it also implies that well validated methods are utilised [7].

Moreover, on the issue of industry needs of metrology, the industrial sector usually incurs errors due to bad measurements and data processing. These translate into waste, bad quality, production decreases and impact on their finances. It is therefore important to recognize the errors and their causes and to be able to have trust in the measuring instruments [9].
Metrology at the technological frontlines enables and facilitates industrial innovation in advanced production and instrumentation [6]. Through the development of measurement techniques, metrology enables innovation of products in many areas, such as in healthcare and assisted living.

Metrology plays an indispensable and integrated role in the automobile industry. Accurate, comparable and traceable measurements of almost all physical quantities and several chemical quantities (e.g. exhaust emissions) is vital for constructing innovative, low-cost, low maintenance, safe, energyeconomic, and environmentally friendly cars in an extremely globalized and internationally competitive market [7]. Dimensional requirements are stricter than ever at the spearhead of some industrial techniques like electronic miniaturization. Seamless interchangeability of components is commonplace owing to gauging and accurate measurements made possible by the advances made in dimensional metrology field [8]. Thus, when conversing about the significance of metrology regarding length measurement, it is not a matter of aggrandizement, but dealing with a very genuine practical need for national economy.

ii. Metrology aid in commerce: In commerce and industry everything is being measured. Thus, the importance of metrology as a science of measurement just can't be ignored. Measurements enter into practically all commercial transactions from the trading of goods to the retail sale of goods in the market place. For example, in oil and gas industry major trade benefits would be obtained if the measurements of flow were significantly more precise, as billions and billions of barrels are measured in oil and gas pipelines and then traded to users. Errors of a few parts per thousand represent some hundreds of millions of dollars [14]. Consider the case where a Pump Station was designed to pump 60,000 gallons per minute (227 cubic meters per minute) of oil. A small error of $0.1 \%$ equates to an error of 2,057 barrels of oil a day. At a spot price of $\$ 105$ a barrel, that $0.1 \%$ error would cost $\$ 216,000$ a day. Over a year, the $0.1 \%$ error would amount to a difference of \$78.8 million. Note that the error could either be on the high side, benefiting the seller; or on the low side, to the buyer's benefit.

At home, people consume electricity, drinking water, gas, heat, all of them measured by meters whose reliability is tested and approved by organisations within the legal metrology system. This is to ensure that these measuring devices will give correct results and that the specified error limits will be maintained during a period of predefined duration. For instance, according to International Committee for Weights and Measures [10], Western European gas consumption in 2000 reached just under 390 billion cubic metre, being about one-fifth 
of total energy demand. One can clearly see that a metering error of $1 \%$ equals about 4 billion cubic metres having a commercial value of 800 million euros per year at a consumer price of 0.20 euro per cubic metre.

Metrology improves fair trade via harmonised written standards, reliable measurement systems and methods, and universally recognized certificates. This makes it possible for a pre-package labelled " 1 kilogram" in any nation to equate to the same measure of product in another nation; parts assembled in one nation fit into devices in another nation, machines type approved for use in one nation could likewise be sold and utilised in another nation, without extra technical inspections [6].

iii. Metrology improves health and promotes the safety of citizens: Calibration and testing of medical devices are some of the most important and critical issues in the field of metrology. Test, measurement and calibration are critically important in achieving quality control of the highest standard in medical equipment. Confidence in medical measurement results helps in deciding if medical treatment is needed or not [11]. When dealing with medicines, incorrect doses can be dangerous. Under dosing may not adequately treat an illness. Overdosing, on the other hand, may cause illness or side effects that can be lethal. This clearly shows that measurement errors in diagnoses and in therapy can cause serious problems, or even death and, for good or bad, we rely more every day on measurements related to health.

Apart from its positive impact in health and safety, measurement is also critical in saving cost. When medical results are accepted and usable everywhere, unnecessary repetition of possibly detrimental diagnostic procedures such as X-ray exposure which could be costly will be minimised. Moreover, during the X-ray exposure the required dose of radiation will not be exceeded [5]. Accurate calibration of medical instruments supports precise and correct diagnosis of disease.

iv. Metrology in aid of food safety: The safety of the food we consume has a direct impact on our well-being and is a determinant for the quality of life. Food testing and the metrological principles associated with this activity play a key role in helping to ensure the safety of the food chain. Food testing is closely associated with public health, chemical and biological testing is used to make decision about food quality. Thus, reliable sampling and measurements are an essential component of proper decision taking [10]. Through certified reference materials, legal metrology provides confidence in these results. v. Metrology aids in environmental protection: Environmental and climate concerns affect our lives, regardless of where we live in many more aspects than we might suppose. Accurate measurements of atmospheric parameters such as air and water quality, electromagnetic and noise pollution, radiation level and extreme meteorological events are fundamental everywhere on our planet. The degradation of the environment from the damaging effects of human and industrial activities be it in the ground, water or in the air, must be measured accurately. Apart from its positive impact in ensuring reliable data for checking conformity to standards and for decision-making related to protective measures, it is also critical in saving cost. For instance, when formal arrangements for emission trading become operative, the costs connected with keeping the environment clean or connected with the cleaning process itself are enormous. Incorrect measurements lead to wrong decisions and may cost the producer or society very large sums of money according to International Committee for Weights and Measures [10].

As we base our lifestyle on so many indirect environmental impacts, e.g. large scale industrial and power plants, each of them require monitoring, measurements and controlling at levels of uncertainty close to, if not equal to the state of the art. We need to improve data quality in essential climate variables to better understand how our climate is changing. Measurements are the basis to guarantee reliable observations and organise mitigation actions for climate change.

vi. Metrology aids regulation: A range of government regulations cover areas such as environmental management, occupational health and safety, traffic control, and air traffic control. Metrology aids regulation by providing measurement references for policy advice, directives, conformity assessment, and verification [6].

vii. Metrology related to the quality of life: Many types of measurements are more or less closely related to what the public perceive as "quality of life". These include measurements of noise (e.g. noise from neighbours, traffic and airport noise), dust (outside and inside), vibration and even measurements of subjective quantities such as taste, smell and appearance (e.g. glossiness of paints is a well-known and critical parameter in paper and car manufacturing). Also in these cases the consumer expects reliable and comparable measurements and specifications [10]. Precise measurement standards can lead to better analysis and understanding of our living environment, for example indoor and outdoor air quality monitoring to protect and improve the quality of life [10]. 


\section{The Current Situation in Metrology Education}

Good metrology systems and qualified specialists can help in increasing productivity and efficiency, improving repeatability by minimizing human errors, increasing customer satisfaction and saving money applying new or suitable technologies for various tasks. Indeed, any nations with the prospect to develop must have an established metrology system which includes training centres, specialized educational institutions and formal metrology education at technical schools and/or university level. Given a basic understanding of metrology, even a non-scientist can begin to engage in a critical analysis of scientific claims across a broad spectrum based on metrological principles [4]. However, the establishment of new metrology systems embedded with qualified specialists in newly independent countries needs special education for the professionals involved in the process. Accredited bodies or personnel of calibration services must have some understanding of calibration, quality standards, regulation, laws and the benefits of them to the society at large. All of this requires some level of education.

Conversely, in many countries, there is inadequate provision for teaching of metrology at every level of the educational system: schools, technical colleges and universities. Metrology often has to be "learned on the job" [2]. In an attempt by the International Committee for Weights and Measures [2] to proffer a solution to this problem, it laid emphasis on training as an important issue that needs to be addressed nationally. However, what must be taken into consideration is that the teaching personnel need to be educated before effective training can take place.
Likewise, the control of Weights and Measures (Legal Metrology) via legal routes to ensure fair transactions and accurate measurements, has from ancient times been considered as an essential duty of a nation. This also demands the need for highly skilled professionals in metrology. As found in the study of Mason [12], the problem of shortage and inadequacy of qualified personnel in metrology has been a general problem that is hindering the progress of many developing countries. He therefore recommended nation to nation training, that is, nations that are most advanced in metrology provide significant training to those that are less advanced. Paradoxically, while it is necessary to use expertise acquired from abroad, it is not usually possible to transfer metrological methodology from the developed countries in a successful manner without the developing countries having a fundamental understanding of metrology.

Many years ago, the George Washington University partnered with the National Bureau of Standards (now the National Institute of Standards and Technology or NIST) to offer graduate programs in metrology, but today, such programs are no longer available [13]. Also, around 1961, the Navy Metrology Engineering Centre at Pomona, CA offered metrology courses in most measurement disciplines. After the mid-sixties, a Tri-Services agreement provided for gradual consolidation of the courses at Lowry. However, such schools is no longer in existence today.

Metrology is not just a pleasure to a very small number of specialized scientists, it is a practical profession, vital for industry development and to the economic growth of nations, although not always recognized as such, the term is narrowly understood even among the educationalists.

Table 1. Educational institutions that offering metrology courses in developing countries $(15,16)$

\begin{tabular}{|c|c|c|}
\hline \multicolumn{3}{|c|}{$\begin{array}{c}\text { EDUCATIONAL INSTITUTIONS THAT OFFER METROLOGY PROGRAMS OR CLASSES IN } \\
\text { DEVELOPING COUNTRIES }\end{array}$} \\
\hline Countries & Educational Institution & Metrology Program \\
\hline BRAZIL & $\begin{array}{l}\text { Instituto de Pesquisase Estudos Industriais } \\
\text { (IPEI) }\end{array}$ & $\begin{array}{l}\text { Institute of Industrial Research and } \\
\text { Studies }\end{array}$ \\
\hline CHINA & University of China Metering, Hangzhou & $\begin{array}{lll}\text { Metrology and } & \text { Measurement } \\
\text { Engineering } & & \\
\end{array}$ \\
\hline KOREA & University of Science and Technology(UST) & \\
\hline \multirow[t]{2}{*}{ MEXICO } & $\begin{array}{l}\text { The Center for Engineering and Industrial } \\
\text { Development (CIDESI) }\end{array}$ & Postgraduate Metrology Programs \\
\hline & $\begin{array}{l}\text { Universidad Politécnica de Santa Rosa } \\
\text { Jáuregui }\end{array}$ & Engineering Industrial Metrology \\
\hline \multirow[t]{2}{*}{ MOROCCO } & $\begin{array}{l}\text { Ecole Spécialisée en Qualité et Métrologie } \\
\text { 4, Rue national, Centre ville de Casablanca }\end{array}$ & Quality management system \\
\hline & $\begin{array}{llll}\text { Nosov } & \text { Magnitogorsk } & \text { State } & \text { Technical } \\
\end{array}$ & Master in Engineering - Standardization \\
\hline
\end{tabular}




\begin{tabular}{|l|l|l|}
\hline \multirow{2}{*}{ RUSSIA } & University & and Metrology \\
\cline { 2 - 3 } & Siberian State Aerospace University & Standardization and Metrology \\
\hline THAILAND & $\begin{array}{l}\text { King Mongkut's University of Technology } \\
\text { Thonburi (KMUTT) }\end{array}$ & Industrial Metrology Program \\
\hline \multirow{3}{*}{ TANZANIA } & College of Business Education, Dar Es Salaam & $\begin{array}{l}\text { Basic Technician Certificate in } \\
\text { Industrial and Legal Metrology }\end{array}$ \\
\hline & $\begin{array}{l}\text { Bachelor in Metrology and } \\
\text { Information-measuring Engineering }\end{array}$ \\
\cline { 2 - 3 } & $\begin{array}{l}\text { National Technical University of Ukraine: Igor } \\
\text { Sikorsky Kyiv Polytechnic Institute }\end{array}$ & $\begin{array}{l}\text { Metrology and Information- } \\
\text { Measurement Engineering" }\end{array}$ \\
\cline { 2 - 3 } & $\begin{array}{l}\text { National Technical University: Kharkiv } \\
\text { Polytechnic Institute }\end{array}$ & $\begin{array}{l}\text { Metrology and Information and } \\
\text { Measuring Equipment }\end{array}$ \\
\hline
\end{tabular}

Table 2. Educational institutions that offer metrology programs or classes in developed countries $(15,16)$

\begin{tabular}{|c|c|c|}
\hline \multicolumn{3}{|c|}{$\begin{array}{l}\text { EDUCATIONAL INSTITUTIONS THAT OFFER METROLOGY PROGRAMS OR CLASSES DEVELOPED } \\
\text { COUNTRIES }\end{array}$} \\
\hline Countries & Educational Institution & Metrology Specialisation \\
\hline \multirow[t]{2}{*}{ AUSTRALIA } & RMIT University, Melbourne, Australia & Metrology Programs \\
\hline & $\begin{array}{l}\text { Macquarie University, Balaclava Road, } \\
\text { North Ryde, NSW, 2109, Australia }\end{array}$ & $\begin{array}{l}\text { Master of Laboratory Quality } \\
\text { Analysis and Management }\end{array}$ \\
\hline BULGARIA & $\begin{array}{lr}\text { South-West } & \text { University } \\
66 \text { Ivan Michailov st., } 2700 \text { Blagoevgrad, } \\
\text { Bulgaria }\end{array}$ & The bachelor program of Metrology \\
\hline \multirow[t]{4}{*}{ CANADA } & $\begin{array}{lcll}\text { Academy } & \text { of } & \text { Applied Pharmaceutical } \\
\text { Sciences Inc., North York (Toronto), } \\
\text { Ontario }\end{array}$ & \\
\hline & $\begin{array}{lccc}\text { Conestoga } & \text { College, } 299 & \text { Doon } & \text { Valley } \\
\text { Drive, Kitchener, Ontario N2G 4M4 }\end{array}$ & $\begin{array}{l}\text { Quality Assurance (Ontario College } \\
\text { Certificate) }\end{array}$ \\
\hline & Fleming College & $\begin{array}{l}\text { Instrumentation and Control } \\
\text { Engineering Technician }\end{array}$ \\
\hline & Seneca College & $\begin{array}{l}\text { Quality Assurance (Seneca College } \\
\text { Certificate) }\end{array}$ \\
\hline ESTONIA & $\begin{array}{l}\text { Applied Measurement Science (AMS), } \\
\text { University of Tartu }\end{array}$ & \\
\hline FINLAND & $\begin{array}{l}\text { Aalto University, Metrology Research } \\
\text { Institute }\end{array}$ & $\begin{array}{l}\text { Aalto University School of Electrical } \\
\text { Engineering }\end{array}$ \\
\hline \multirow[t]{2}{*}{ FRANCE } & \begin{tabular}{lll} 
Ecole Supérieure de & \multicolumn{2}{c}{ Métrologie } \\
Ecole des Mines de & Douai \\
Dpt Métrologie-Qualité & &
\end{tabular} & $\begin{array}{l}\text { Mastère spécialisé en Systémes de } \\
\text { Mesure et Métrologie }\end{array}$ \\
\hline & University of Reims Champagne Ardenn & $\begin{array}{l}\text { Professional Undergraduate Degree in } \\
\text { Sensors, Instrumentation, Metrology } \\
\text { (CIM) }\end{array}$ \\
\hline \multirow[t]{2}{*}{ GERMANY } & $\begin{array}{l}\text { Braunschweig International Graduate School } \\
\text { of Metrology (IGSM) }\end{array}$ & $\begin{array}{l}\text { international metrological training } \\
\text { centre }\end{array}$ \\
\hline & $\begin{array}{l}\text { Friedrich-Alexander-Universität Erlangen- } \\
\text { Nürnberg FAU }\end{array}$ & $\begin{array}{lll}\text { MSc in } & \text { Advanced } & \text { Optical } \\
\text { Technologies } & & \end{array}$ \\
\hline LITHUANIA & $\begin{array}{l}\text { KTU Institute of Metrology, Kaunas } \\
\text { University of Technology }\end{array}$ & \\
\hline IRELAND & Institute of Technology Sligo & $\begin{array}{l}\text { BEng in Precision Engineering and } \\
\text { Design }\end{array}$ \\
\hline
\end{tabular}




\begin{tabular}{|c|c|c|}
\hline ITALY & $\begin{array}{l}\text { Politecnico di Torino in convention with } \\
\text { Istituto Nazionale di Ricerca Metrologica } \\
\text { (I.N.Ri.M.) }\end{array}$ & science of measurement \\
\hline SLOVAK REPUBLIC & & PhD SJF 5.2.55. Metrology \\
\hline SWEDEN & $\begin{array}{l}\text { Department of Measurement Technology, } \\
\text { SP Technical Research Institute of Sweden }\end{array}$ & $\begin{array}{l}\text { Metrology and quality-assured } \\
\text { measurement }\end{array}$ \\
\hline \multirow[t]{2}{*}{ UNITED KINGDOM } & Coventry University & Foundation Degree in Metrology \\
\hline & University of Huddersfield & Advanced Metrology \\
\hline \multirow{19}{*}{ US } & $\begin{array}{llr}\text { University of } & \text { North Carolina at } & \text { Charlotte } \\
\text { Center } & \text { for Precision } & \text { Metrology } \\
9201 & \text { University } \quad \text { City } & \text { Blvd } \\
\text { Charlotte NC } 28223 & & \end{array}$ & Center for Precision Metrology \\
\hline & $\begin{array}{l}\text { California State University Dominguez Hills } \\
\text { Carson. }\end{array}$ & $\begin{array}{l}\text { Certificate of completion in } \\
\text { Metrology; Master of Science Quality } \\
\text { Assurance }\end{array}$ \\
\hline & California National University, Torrance & $\begin{array}{l}\text { Bachelor of Quality Assurance } \\
\text { Science Degree Program }\end{array}$ \\
\hline & Northern Illinois University, Dekaib & $\begin{array}{l}\text { Quality Control of Manufacturing } \\
\text { Processes (Certificate of Graduate } \\
\text { Study) }\end{array}$ \\
\hline & $\begin{array}{l}\text { Purdue University - College of Technology } \\
\text { West Lafayette, IN }\end{array}$ & \\
\hline & Eastern Kentucky University, Richmond & Applied Engineering \& Technology \\
\hline & Idaho State University, Pocatello & $\begin{array}{l}\text { Master of Science in Measurement } \\
\text { and Control Engineering }\end{array}$ \\
\hline & $\begin{array}{l}\text { Ferris State University at Grand Rapids, Big } \\
\text { Rapids, Michigan } 49307\end{array}$ & Quality Technology, Certificate \\
\hline & University of Central Florida, Orlando & $\begin{array}{lll}\begin{array}{l}\text { Quality } \\
\text { Certificate }\end{array} & \text { Assurance } & \text { Graduate } \\
\end{array}$ \\
\hline & $\begin{array}{l}\text { Vincennes University, Indiana, Haas } \\
\text { Technical Education Centres, Vincennes }\end{array}$ & Vocational Metrology Training \\
\hline & $\begin{array}{l}\text { Alamo Colleges: St. Philip's College, } 1801 \\
\text { Martin Luther King Drive, San Antonio, } \\
\text { Texas } 78203\end{array}$ & Precision Tools and Measurements \\
\hline & $\begin{array}{l}\text { Butler County Community College, Butler, } \\
\text { Pennsylvania }\end{array}$ & $\begin{array}{l}\text { Measurment Science/Metrology } \\
\text { Technology, A.A.S }\end{array}$ \\
\hline & Central Community College, Columbus, NE & \\
\hline & $\begin{array}{l}\text { Central Georgia } \quad \text { Technical } \\
\text { Macon, }\end{array}$ & $\begin{array}{l}\text { AAS Metrology; Metrology Diploma; } \\
\text { Electrical Metrology Certificate; } \\
\text { Physical Metrology Certificate }\end{array}$ \\
\hline & Cerritos College, Norwalk & $\begin{array}{l}\text { Coordinate Metrology, Certificate of } \\
\text { Achievement }\end{array}$ \\
\hline & $\begin{array}{l}\text { Danville Community College, Danville, } \\
\text { Virginia }\end{array}$ & Dimensional Inspection (Metrology) \\
\hline & Fox Valley Technical College, Wisconsin & $\begin{array}{l}\text { Production Inspection \& Metrology } \\
\text { (Certificate) }\end{array}$ \\
\hline & Front Range Community College, Longmont & 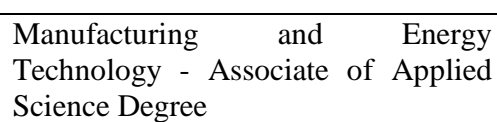 \\
\hline & Joliet Junior College, Joliet & $\begin{array}{l}\text { Dimensinal Metrology (Certificate of } \\
\text { Completion (CCO) ) }\end{array}$ \\
\hline
\end{tabular}




\begin{tabular}{|l|l|l|}
\hline & $\begin{array}{l}\text { Madison Area Technical College, Madison } \\
\text { Miwaukee Area Techical College }\end{array}$ & $\begin{array}{l}\text { Dimensioning/GDT; Elements of } \\
\text { Basic Metrology; Intermediate } \\
\text { Metrology Applications } \\
\text { Quality Engineering Technology, } \\
\text { Associate in Applied Science Degree }\end{array}$ \\
\hline
\end{tabular}

\begin{tabular}{|c|c|c|}
\hline \multirow{9}{*}{ US } & $\begin{array}{l}\text { Monroe County Community College } \\
\text { Monroe, }\end{array}$ & AAS Metrology Technology \\
\hline & Nashua Community College & $\begin{array}{l}\text { Metrology and Quality Control for } \\
\text { Precision Manufacturing Certificate }\end{array}$ \\
\hline & Navajo Technical University, Crownpoint & $\begin{array}{ll}\text { Advanced } & \text { Manufacturing } \\
\text { Technology B.A.S. } & \end{array}$ \\
\hline & New Jersey Institute of Technology & $\begin{array}{ll}\text { Manufacturing } & \text { Engineering } \\
\text { Technology (MNET) } & \end{array}$ \\
\hline & $\begin{array}{lll}\text { Piedmont } & \text { Technical } & \text { College } \\
\text { Greenwood, SC } & & \end{array}$ & Precision Metrology Certificate \\
\hline & $\begin{array}{l}\text { Red Rocks Community } \quad \text { College, } \\
\text { Lakewood }\end{array}$ & $\begin{array}{lll}\text { Metrology } & \text { Quality } & \text { Control } \\
\text { Certificate } & & \end{array}$ \\
\hline & $\begin{array}{l}\text { Ridgewater } \\
\text { Hutchinson }\end{array}$ & $\begin{array}{lll}\text { Calibration } & \text { and } & \text { Metrology } \\
\text { Technology } & & \end{array}$ \\
\hline & $\begin{array}{l}\text { Rock } \\
\text { Rockford, IL 61114 }\end{array}$ & $\begin{array}{ll}\text { Manufacturing } & \text { Engineering } \\
\text { Technology (MET) Degree }\end{array}$ \\
\hline & $\begin{array}{ll}\text { Sinclair } & \text { Community } \\
\text { Dayton, Ohio } & \end{array}$ & Operational Technology \\
\hline
\end{tabular}

Considering the vast benefits of metrology depicted above, metrology is a unique program that needs to be incorporated into schools, technical colleges and universities academic curricula. Yet, the prosperity of this knowledge has not been evenly spread throughout the world. There remain considerable differences between and within regions, countries and societies. Too often, lack of metrological education has left significant segments of the countries affected behind. This is particularly so in the case of Nigeria.

\section{Metrology in Nigeria}

To demonstrate the level of metrology education in developing countries, Nigeria has been used as a case study. The oil and gas industry are the main source of Gross Domestic Product [GDP] in Nigeria with about $\$ 8$ billion spending annually in servicing the industry, with the figure projected to hit $\$ 15$ billion in next few years according to Omenikolo \& Amadi [17]. Despite the huge sums of money spent on this industry, the Nigeria Extractive Industry Transparency Initiatives [18 and 19] audit report reflected insufficient measurement control across the sector. Since the degree of development of metrology in a country also reflects the stage of development of that country's industry according to Zaimović-Uzunović and Lemeš [20], execution of the measurement in the sector by non-experts in metrology or lack of metrological knowledge by the designated bodies in charge of the regulation of the measurement activities could lead to insufficient measurement control.

Taking into consideration the metrological knowledge required for effective measurement control to be achieved in the sector and the recruitment criteria of the bodies in charge of the measurement control of this industry which include: the oil and gas operators; the DPR (Department of Petroleum Resource) which is the body charged with the legal responsibility of regulating, monitoring and supervising the measurement activities in the industry; and the Weights and Measures Bureau (the legal metrology body bestowed with the responsibilities of supervising and ensuring accurate calibration and certification of measuring devices used for custody transfer measurement system and type evaluation and verification of all the measurement devices), the knowledge gaps of the students were evaluated in the areas of general, legal and flow metrology. This was to evaluate the capability of tomorrow's professionals relative to the metrological knowledge necessary to form stronger metrology bodies capable of maximising the economic recovery of Nigeria oil and gas through sufficient measurement control. The research has been conducted across six universities with the survey population of the study made up of students from engineering and science disciplines. The research examined knowledge required in basic, flow and legal metrology by intensive investigation 
through interviews and questionnaires. The scope of the research comprised metrological knowledge that will enable new graduates to make productive contributions to the Nigeria oil and gas industry.

\subsection{Survey methodology}

The survey was conducted through a combination of interviews and questionnaires.

The interviews were designed to confirm the extent of the students' fundamental knowledge of metrology. The interviews were structured around the following questions:

Q1. What do you understand by the term metrology?

Q2. What are the benefits of metrology to the society?

Q3. What are the categories of metrology?

Q4. What do you understand by the term scientific and industrial metrology and their related field?

Q5. What is legal metrology and what is their benefit to the society?

Q6. What do you understand by the term metrological control and what are the basic elements?

Q7. What do you understand by term measurement uncertainty?

Q8. What do you understand by the term traceability of standard?

Q9. What is calibration and why calibrate?

10 What are the differences between verification and calibration?

For the questionnaire, since the oil and gas industry are a major user of flow measurement and the legal metrology bureau is responsible for the metrological control of the sector, the questions covered topics across a variety of subjects related to flow metrology and legal metrology. The questionnaire was designed to determine if the future professionals will be able to make a significant contribution to the management of the measurements activities in the Nigeria oil and gas industry. The questionnaire then asked 10 broad questions and offered several selections to rate on a scale 1(Unknowledgeable), to 3 (Knowledgeable). Questions 11 through 20 are as follow:

Look at the listed educational knowledge and skills critically and choose from the options base on your knowledge and skill level. Selection range: 1(Unknowledgeable), 2 (Somewhat knowledgeable) to 3 (Knowledgeable).

Q11. Principles and practice of flow measurements Q12. Oil and gas custody transfer measurement system

Q13. Legal metrology requirements of oil and gas custody transfer measurement

Q14. Fiscal oil measurement uncertainty requirement Q15.Fiscal gas measurement uncertainty requirement
Q16. How to inspect and verify gas measurement systems

Q17. How to inspect and verify liquid measuring systems

Q18. How to inspect and verify bulk storage measurement systems

Q19. Sources of error and mismeasurement within metering systems

Q20. Standards available for petroleum measurement

Respondents' identities and the universities with which they affiliate remain confidential; however, they clearly represent a cross-section of engineering and science students in Nigeria.

\subsection{Results}

The views of 1017 students of science and engineering disciplines were obtained. $25 \%$ of the students were in 500 level, 35\% 400 level, 30\% 300 level and 10\% 200 level. The results of the interview and questionnaires were analysed using univariate descriptive statistics. Questionnaire with no answer were assigned an interest number of 0 . The reflection of the self-assessment and assessment of the students with respect to their knowledge gap in metrology are shown in Figure 2 below.

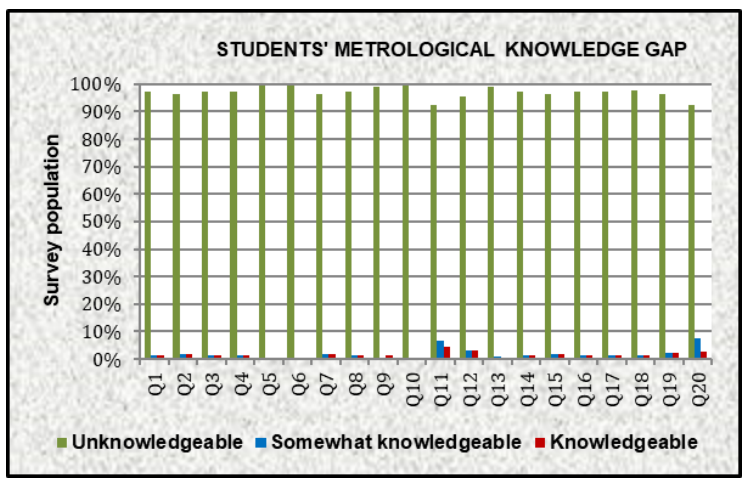

Figure 2. Knowledge gap of the students

As shown in Figure 2, in all the aspects of metrology examined, self-assessment and assessment of the students reveals they all certainly lacked the required competencies. Familiarity with legal metrology is below $1 \%$. At present, based on the survey results, Nigerian Universities cannot produce graduates suitable for metrological development. Courses specialising in metrology have never been offered at either undergraduate or postgraduate levels. With the research outcome, one can deduce that the insufficient measurement control Nigeria is facing within its petroleum industry is due to the fact that most of the bodies in charge of the sector are insufficiently trained or experienced in metrology. 


\section{Recommendations}

Metrology education is indispensable to developing countries for their economy and for attracting investment. Unfortunately, this subject area is generally weak within the educational institutions in the developing countries. While it is necessary to use expertise acquired from abroad as recommended by Zaimović-Uzunović and Lemeš [14] and Mason [6], developing countries must also make an effort to integrate metrology programmes into their academic curriculum.

In order to have manpower experienced in scientific, industrial and legal metrology to keep pace with the needs of industry and society, every country must have a well-established metrology system with adequate metrology training centres, specialized educational institutions and, of course, formal metrology education at technical school and university levels. In addition, the curricula of engineering schools, technical universities and other special training institutes should contain at least some basic courses on metrology. To facilitate this, consortia of institutions comprised of educational institutions, industry practitioners, and regulators also need to be formed.

Since before the field of metrology can advance in line with the growth in a particular branch of industry, it is necessary to provide the appropriate personnel [14], developing countries must also make an effort to penetrate the domain of metrology program. The program should consist of compulsory courses covering fundamental skills and knowledge about metrology; general courses dealing with more specialised and advanced topics; and elective courses where students are able to choose the courses which suit their professional needs. These will define the requirement for a suitable metrology education.

Thus, if we are going to secure the flow of talent into metrology, to enable purposeful and effective early intervention to enthuse tomorrow's metrologist, we need to start at the very beginning. An education and training in metrology is therefore essential for everyone, starting from primary education, though secondary education and in many cases higher education and professional training. Education is the means which will allow spreading metrology and its importance to society and to the industrial sector. The use of metrology as a basic tool of study and analysis allows assimilation of everything what surrounds us, from the simplest to the most complex thing.

The best mechanism of transferring metrological knowledge is by incorporating it into university academic curricula, no undergraduate course should go without these basic elements. The effects of this lack of knowledge are apparent already in advanced bachelor courses, during the master study and even in technical reports and papers.

\section{Conclusions}

This paper presents the significance of metrology and the weakness among the educational institutions in developing countries. The metrological knowledge assessment conducted across some Nigerian universities used as a case study provides clear evidence of the level of the weakness. Therefore, considering the importance of metrology to the development of a nation, it is crucial for the educational institutions in the developing countries to introduce metrology into their academic curricula.

\section{References}

[1] Addey, M., G. Faculty, G., (2014). Organization of legal metrology in the worldwide standards of weights and measurements, pp.24-27.

[2] International Committee for Weights and Measures, National and international needs relating to metrology: International collaborations and the role of the BIPM, CIPM, Paris, 1998.

[3] Vosk, T., Emery, A.F., (2015). Forensic Metrology Scientific measurement and inference for Lawyers, Judges, and Criminalists. Boca Raton: CRC Press.

[4] Vosk, T., (2014). Forensic Metrology - A Primer for Lawyers and Judges (2nd ed.). Bothell: Theodore Wayne Vosk.

[5] Martin, J.T., (2016). The Importance of Global Metrology for Standards, Industry and Trade: Metrology in a Dynamic World, BIPM.

[6] OIML D1, (2012). Considerations for a law on metrology (E ed.). OIML: International Document.

[7] European Commission, (1998). Metrology in chemistry and biology: a practical approach. (EUR 18405 EN). Directorate-General Science, Research and Development: Belgium.

[8] Terriek, J., (1972). Fundamental Metrology: Present State and Recent Progress in some Important Fields of Fundamental Metrology, and Functions of Consultative Committees of the International Committee of Weights and Measures. The leading international journal in pure and applied metrology. 8, 99-108.

[9] S. Martínez-Sanchez, S., Laguna-Aguilar, F.M.C., Torres-Guzman, J. C., (2007). Metrology impact in Technological Universities, Mex ico. In IMEKO 20th TC3, 3rd TC16 and 1st TC22 International Conference Cultivating metrological knowledge 27th to 30th November. Merida, Mexico, 2007. Retrieved from http://www.imeko.org/publications/tc3-2007/IMEKOTC3-2007-089u.pdf

[10] International Committee for Weights and Measures. evolving needs for metrology in trade, industry and society 
and the role of the BIPM. (ISSN 1025-0034). Paris: Stedi Media, 2003.

[11] Marban, R.M., Pellecer, J.A., (2003). Legal Metrology (1st ed.). Centro America: 2001 Produccion y Servicios Incorpoados S.A, 2003.

[12] Mason, H.L., (1968). Making valuable measurements, National Bureau Standard, United State, 1968.

[13] Stein, P., (2001). Measures to Measures: The education of metrology, 2001. Retrieved from http://asq.org/quality-progress/2001/01/measure-formeasure/the-education-of-a-metrologist.html. (Accessed 10 March 2017).

[14] United Nations Department of Economic and Social Affairs, (2015). United Nations Conference on Trade and Development, and the five United Nations regional commissions. World Economics Situations and Prospects, United Nations, New York.

[15] NCSL International, International Institutions Offering Metrology Programs, 2017. Retrieved from http://www.ncsli.org/I/vEDM/RL/International_Institution s/vEDM/IEI.aspx?hkey=d1f353cd-9d26-4b0d-9bddf1abd03769b8. (Access date: 7 March 2017).

[16] Cal Lab, Education, (2017). Retrieved from https://www.callabmag.com/education-training/. (Access date: 1 April 2017).

[17] Omenikolo, I.A., Amadi, R.O., (2010). Challenges facing Nigerian local content in oil and gas industry, Continental J. Renewable Energy, Nigeria, pp, 15-20.

[18] Nigeria Extractive Industries Transparency Initiatives, Report of the physical Audit 1999-2004, (H/243, 245/ccl), Hart Group, SS Afemikhe Consulting Ltd and CMA Ltd, Nigeria: 2006.

[19] Nigeria Extractive Industries Transparency Initiatives, (2009). Summary of recommendations and proposed actions, (H/317/c), Hart Group, SS Afemikhe Consulting Ltd and CMA Ltd, Nigeria.

[20] Zaimović-Uzunović, N., Lemeš, S., (2008). Importance of metrology education - B\& H Case, In 1st Regional Metrology Organisations Symposium - RMO 2008; 20th International Metrology Symposium, CavtatDubrovnik, Croatia. 